\title{
Bilans stanu zasobów gazu ziemnego na przykładzie złóż Niżu Polskiego
}

\begin{abstract}
Głównym regionem występowania złóż gazu ziemnego w naszym kraju jest Niż Polski. Złoża tego surowca są znane z przedgórza Karpat, jak również z Karpat i polskiej strefy ekonomicznej Bałtyku, gdzie niewielkie zasoby gazu występują w małych złożach. Około 75\% zasobów gazu znajduje się w utworach miocenu i czerwonego spągowca, a pozostałe w utworach kambru, dewonu, karbonu, cechsztynu, jury i kredy. Monoklina przedsudecka jest megastrukturą zbudowaną z kilku kompleksów strukturalnych: kaledońskiego, waryscyjskiego, laramijskiego oraz pokrywy polaramijskiej. Z punktu widzenia rozpoznania warunków akumulacji interesujące są kompleksy waryscyjski oraz laramijski. Kompleks waryscyjski, stanowiący podłoże dla utworów permu, zbudowany jest w swej najwyższej części z utworów karbońskich, wykazujących wysoki stopień zaangażowania tektonicznego. Utwory te uległy silnym procesom erozyjno-denudacyjnym, w wyniku których ukształtowała się ich powierzchnia morfologiczna. W 2015 roku stan wydobywalnych zasobów gazu ziemnego w Polsce wynosił 125,04 mld ${ }^{3}$ (zasoby bilansowe i pozabilansowe) i w porównaniu z rokiem poprzednim zasoby te zmniejszyły się o $4,7 \mathrm{mld}^{3}$. Ubytek powstał głównie w wyniku wydobycia. W 2015 roku udokumentowano złoże Sieraków (udokumentowano zasoby wydobywalne - 93,91 $\mathrm{mln}^{3}$ ). Zasoby wydobywalne zagospodarowanych złóż gazu ziemnego wynoszą 102,34 $\mathrm{mld} \mathrm{m}^{3}$, co stanowi $82 \%$ ogólnej ilości zasobów wydobywalnych. Zasoby przemysłowe w 2015 roku wynosiły $54,91 \mathrm{mld} \mathrm{m}^{3}$. Biorąc pod uwagę poszczególne regiony geologiczne Polski zasobne w gaz ziemny, przeprowadzono analizę wielkości zasobów wydobywalnych, przemysłowych i wydobycia na przestrzeni lat 2007-2015.
\end{abstract}

Słowa kluczowe: bilans zasobów złóż gazu ziemnego.

\section{The balance of the state of natural gas resources on the example of the south-western Polish deposits}

The main region of occurrence of natural gas deposits in our country is Niż Polski. These deposits are known from the Carpathian Foreland as well as from the Carpathians and the Polish Baltic Sea Region, where inconsiderable gas resources are found in small deposits. Approximately $75 \%$ of the gas resources are found in the Miocene and red spade, and the remaining in Cambrian, Devonian, Carboniferous, Zeissstein, Jurassic and Cretaceous. The Fore-Sudon Monoclinic is a megastructure built of several structural complexes: Caledonian, Variscan, Laramie and the Polar Cap. From the point of view of the recognition of the conditions of accumulation, of interest are the Variscan and Larameric complexes. The Vicar Scale, which forms the backbone of the Permian Formations, is built in the highest part of the Carboniferous, with a high degree of tectonic involvement. These works underwent strong erosion-denuding processes as a result of their morphological surface. In 2015, the state of extraction of natural gas resources amounted to 125.04 billion $\mathrm{m}^{3}$ (balance sheet and off-balance sheet resources) and decreased by 4.7 billion $\mathrm{m}^{3}$ as compared to the previous year. The depletion of resources was mainly due to extraction. In 2015, the Sieraków deposit was documented (93.91 million $\mathrm{m}^{3}$ was documented). The extracted resources of the developed natural gas fields are 102.34 billion $\mathrm{m}^{3}$, which accounts for $82 \%$ of the total amount of extracted resources. Industrial production in 2015 was 54.91 billion $\mathrm{m}^{3}$. Taking into account the various geological regions of Poland, which are rich in natural gas, an analysis of the volume of recoverable, industrial and extracted natural resources from 2007 to 2015 was done.

Key words: balance of the state of natural gas resources.

\section{Wstęp}

Głównym regionem występowania złóż gazu ziemnego w naszym kraju jest Niż Polski. Złoża tego surowca są znane z przed- górza Karpat, jak również z Karpat i polskiej strefy ekonomicznej Bałtyku, gdzie niewielkie zasoby gazu występują w małych 
złożach [1-9, 15]. Około 75\% zasobów gazu znajduje się w utworach miocenu i czerwonego spagowca, a pozostałe w utworach kambru, dewonu, karbonu, cechsztynu, jury i kredy [9].

W 2015 roku stan wydobywalnych zasobów gazu ziemnego na Niżu wynosił 125,04 $\mathrm{mld} \mathrm{m}^{3}$ (zasoby bilansowe i pozabilansowe), co oznacza, że w porównaniu z rokiem poprzednim zasoby zmniejszyły się o $4,7 \mathrm{mld}^{3}$. Ubytek powstał głównie w wyniku wydobycia. W 2015 roku udokumento-

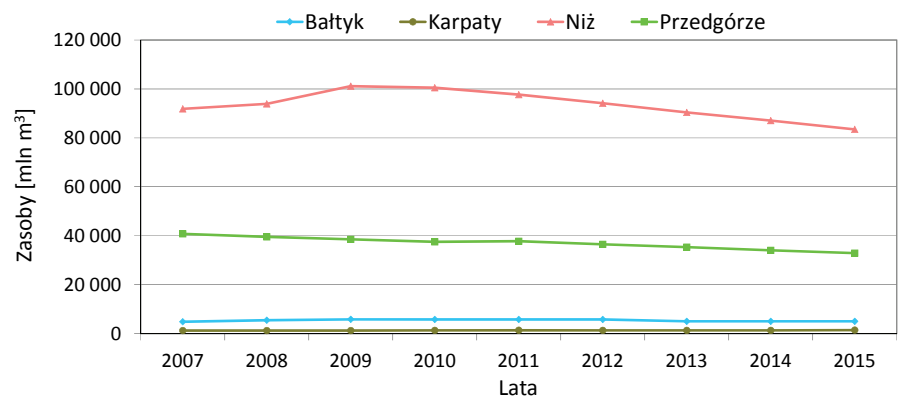

Rys. 1. Wykres wielkości zasobów wydobywalnych gazu ziemnego na przestrzeni lat 2007-2015 w poszczególnych regionach Polski (według bilansów zasobów PIG - PIB [1-9]) wano złoże Sieraków (udokumentowano zasoby wydobywalne $-93,91 \mathrm{mln}^{3}$ ). Zasoby wydobywalne zagospodarowanych złóż gazu ziemnego wynoszą 102,34 mld m³ , co stanowi $82 \%$ ogólnej ilości zasobów wydobywalnych (rysunek 1). Zasoby przemysłowe w 2015 roku wynosiły 54,91 $\mathrm{mld} \mathrm{m}^{3}$.

W 2015 roku wydobycie gazu ziemnego ze złóż o zasobach udokumentowanych wynosiło 5,214 $\mathrm{mld}^{3}$ i było o $0,045 \mathrm{mld} \mathrm{m}^{3}$ mniejsze niż w 2014 roku [14] (rysunek 2).

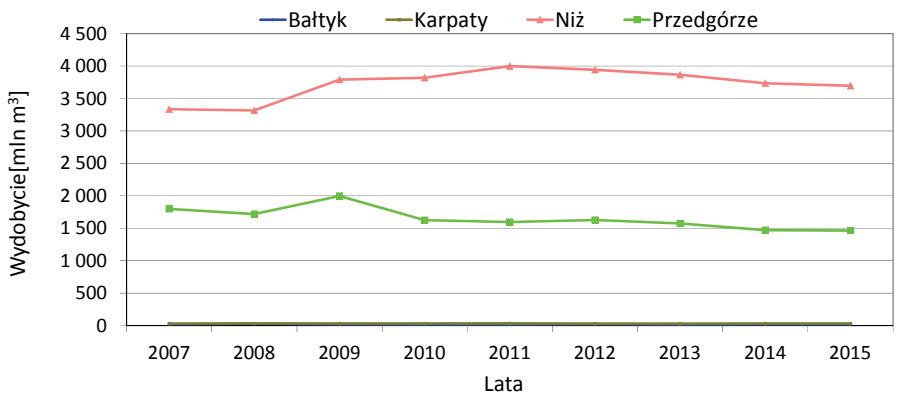

Rys. 2. Wykres wielkości wydobycia gazu ziemnego na przestrzeni lat 2007-2015 w poszczególnych regionach Polski (według bilansów zasobów PIG - PIB [1-9])

\section{Niż Polski}

Monoklina przedsudecka jest megastrukturą zbudowaną z kilku kompleksów strukturalnych: kaledońskiego, waryscyjskiego, laramijskiego oraz pokrywy polaramijskiej. Z punktu widzenia rozpoznania warunków akumulacji interesujące są kompleksy waryscyjski oraz laramijski. Kompleks waryscyjski, stanowiący podłoże dla utworów permu, zbudowany jest w swej najwyższej części z utworów karbońskich, wykazujących wysoki stopień zaangażowania tektonicznego. Utwory te uległy silnym procesom erozyjno-denudacyjnym, w wyniku których ukształtowała się ich powierzchnia morfologiczna. W zasięgu monokliny zaznacza się występowanie kilku elementów strukturalno-erozyjnych [10-12, 14] (rysunek 3):

- blok przedsudecki,

- zapadlisko zielonogórskie, wypełnione osadami saksonu,

- wał wolsztyński, o długości około 200 km i szerokości $30 \div 50 \mathrm{~km}$, w większości pozbawiony osadów saksonu,

- zapadlisko poznańskie, wypełnione klastycznymi osadami saksonu z udziałem zlepieńców w strefach brzeżnych,

- wyniesienie Myśliborza-Rokietnicy,

- zapadlisko pomorskie.

Utwory czerwonego spągowca zalegają niezgodnie na sfałdowanym i zerodowanym podłożu karbońskim i starszym (ry- sunek 4). Utwory te, o bardzo zmiennej miąższości, składają się z serii piaskowcowo-zlepieńcowo-mułowcowych o zabarwieniu ceglastoczerwonym, z niewielkim udziałem utworów szarych. Powstały w warunkach lądowych jako wynik działalności sedymentacji rzecznej, sedymentacji w zbiornikach wód śródlądowych, jak też działalności eolicznej. Wśród tych osadów znajdują się również osady pochodzenia morskiego, jako wynik chwilowych ingresji morskich. Utwory czerwonego spągowca dzieli się na dwa podpiętra: autun i sakson. Na pograniczu autunu i saksonu przypada nasilenie ruchów epejrogenicznych głównej fazy saalskiej, które spowodowały dość wyraźne zmiany paleogeograficzne, tym samym nastąpiła zmiana warunków sedymentacyjnych [10-12, 14].

Utwory wapienia podstawowego charakteryzują się wykształceniem węglanowym w postaci wapieni i dolomitów beżowych i szarobeżowych, twardych, spękanych, sporadycznie silnie porowatych, onkolitowych z wtrąceniami i przerostami anhydrytu. Od góry osady wapienia podstawowego ekranują wyższe poziomy cyklotemu Werra, wykształcone w postaci anhydrytów i soli. Charakter strukturalny poziomu wapienia podstawowego można uważać za zbliżony do obserwowanego w poziomie czerwonego spągowca [10-12, 14, 16-20].

\section{Zasoby Niżu Polskiego}

Zasoby gazu ziemnego na Niżu Polskim znajdują się, według bilansów zasobów Państwowego Instytutu Geologicz- nego - Państwowego Instytutu Badawczego, w około 150 złożach [1-9]. Do analizy zasobów zostało przeznaczonych 


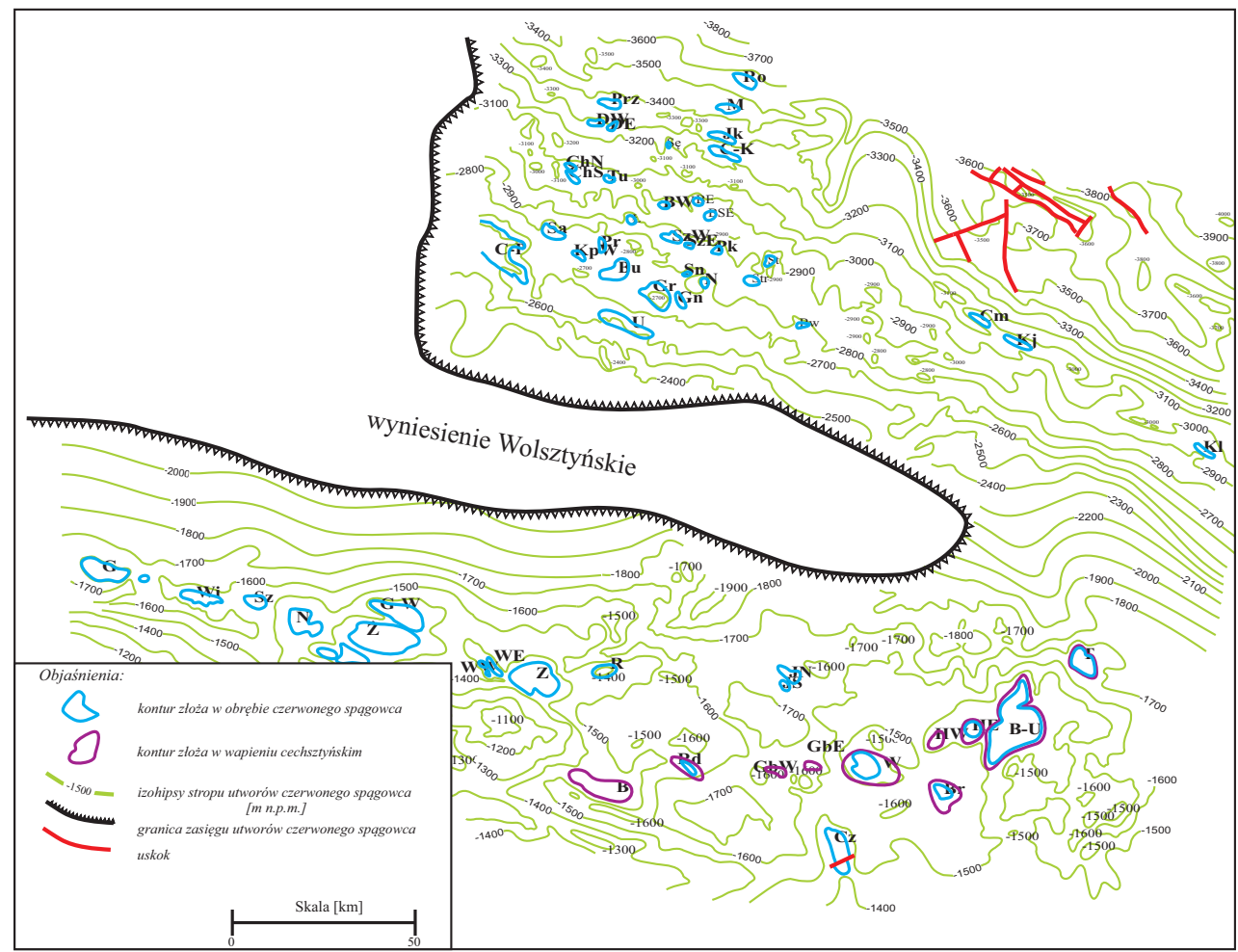

Rys. 3. Mapa strukturalna stropu czerwonego spągowca monokliny przedsudeckiej (według W. Piesik-Buś)

69 złóż (z zestawień otrzymanych z PGNiG SA, Oddział Zielona Góra). Zasoby gazu tych złóż podzielono na zasoby początkowe geologiczne, początkowe wydobywalne i początkowe przemysłowe. Początkowe zasoby geologiczne tych złóż wynosiły $169452,41 \mathrm{mln} \mathrm{m}^{3}$ gazu, początkowe zasoby wydobywalne - $146086 \mathrm{mln} \mathrm{m}^{3}$ gazu, a początkowe zasoby przemysłowe $-95772,82 \mathrm{mln}^{3}$ gazu. Według bilansu PIG - PIB z 2015 roku [9] zasoby wydobywalne z tych złóż wynosiły $62314,23 \mathrm{mln} \mathrm{m}^{3}$, zasoby przemysłowe - $41516,66 \mathrm{mln} \mathrm{m}^{3}$, a wydobycie w 2015 roku - 3697,13 $\mathrm{mln}^{3}$.

Na podstawie bilansu zasobów gazu z 2015 roku rozdzielono zasoby na wydobywalne bilansowe i przemysłowe [9]. Następnie, po przeglądzie zasobów, wydzielono złoża o zasobach wydobywalnych bilansowych do

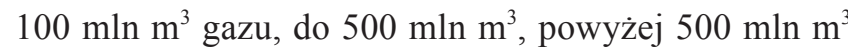
i powyżej $1 \mathrm{mld} \mathrm{m}^{3}$. Okazało się, że 21 złóż z Niżu posiada zasoby wydobywalne bilansowe do $100 \mathrm{mln} \mathrm{m}^{3}$, 28 złóż zasoby do $500 \mathrm{mln} \mathrm{m}^{3}, 7$ złóż zasoby powyżej $500 \mathrm{mln} \mathrm{m} \mathrm{m}^{3}$ i 13 złóż zasoby powyżej $1 \mathrm{mld} \mathrm{m}^{3}$. Jeśli chodzi o zasoby przemysłowe w 2015 roku, również zostały one podzielone w ten sam sposób co zasoby wydobywalne. 31 złóż z Niżu posiada zasoby przemysłowe do

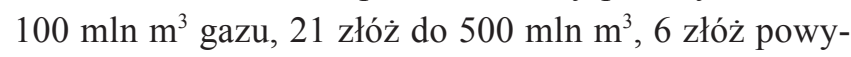
żej $500 \mathrm{mln} \mathrm{m}^{3}$ i 8 złóż powyżej $1 \mathrm{mld} \mathrm{m}^{3}$ (rysunki 5 i 6). Łącznie ze złóż Niżu Polskiego w 2015 roku wydobyto $3697,13 \mathrm{mln} \mathrm{m}^{3}$ gazu.

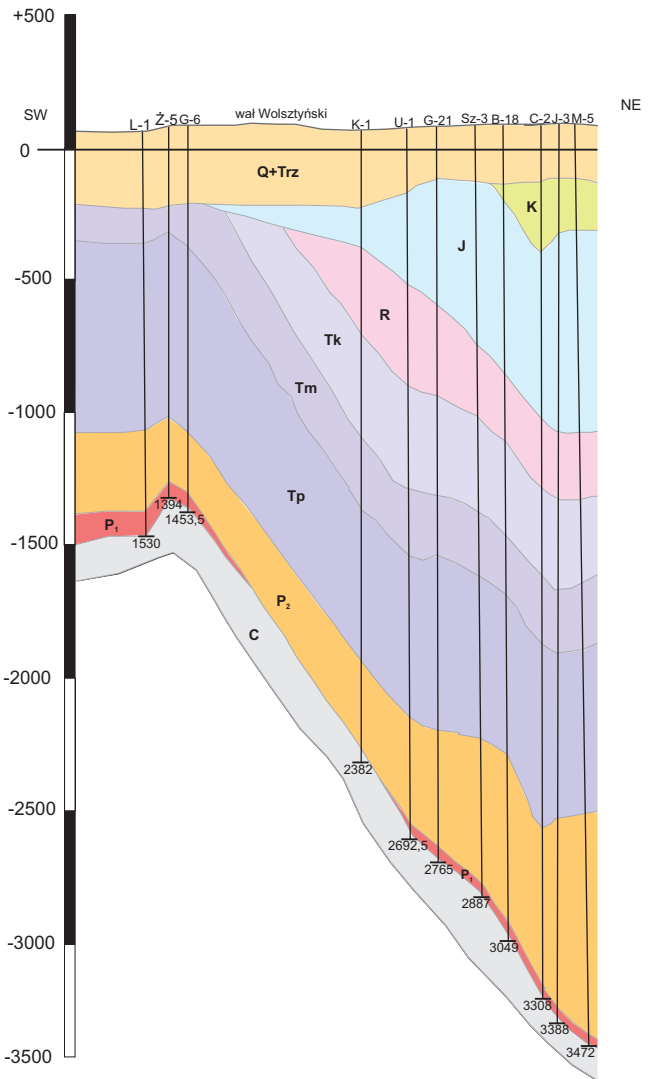

Objaśnienia:

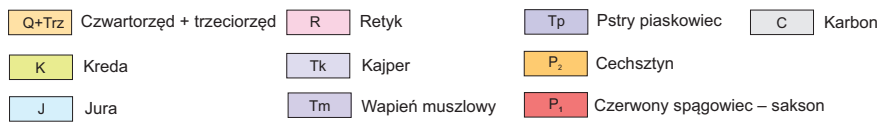

Rys. 4. Przekrój geologiczny poprzeczny przez utwory monokliny przedsudeckiej (według W. Piesik-Buś) 


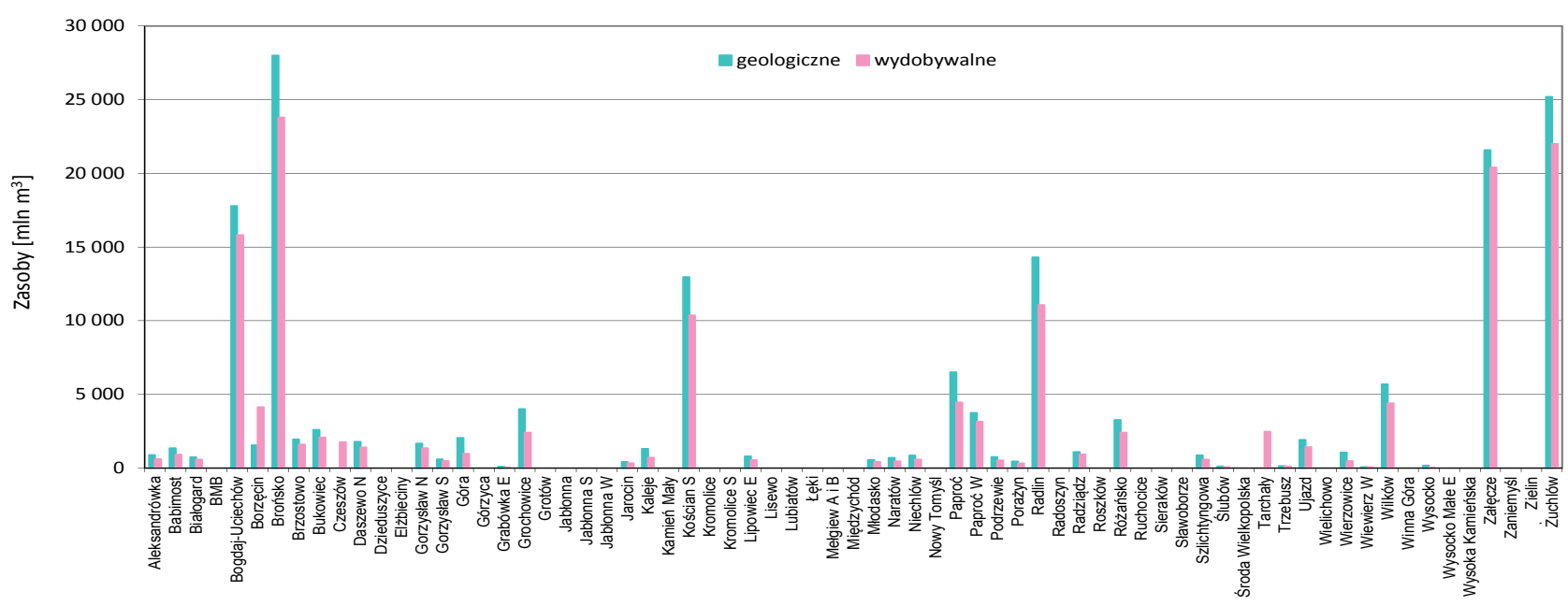

Rys. 5. Zestawienie początkowych zasobów geologicznych i wydobywalnych gazu ziemnego w poszczególnych złożach gazowych Niżu Polskiego (według bilansów zasobów PIG - PIB [1-9])

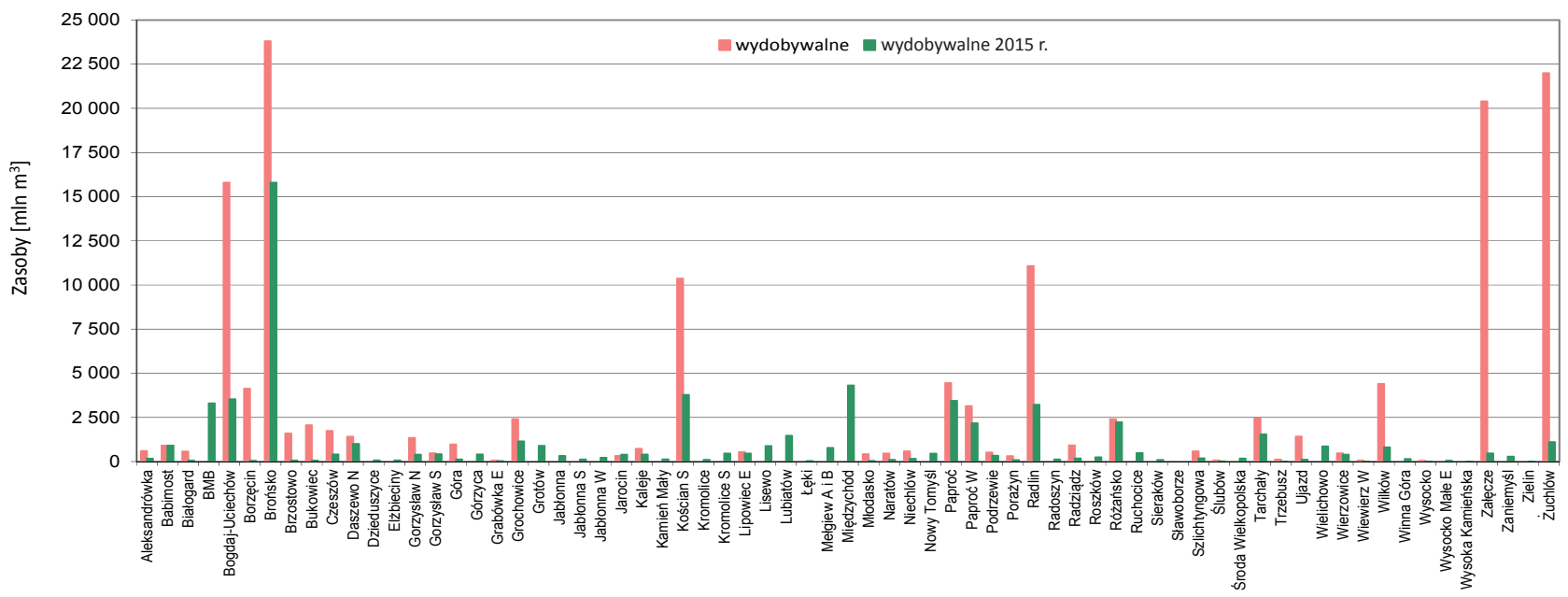

Rys. 6. Zestawienie początkowych zasobów wydobywalnych i zasobów wydobywalnych gazu ziemnego według stanu na 31.12.2015 r. w poszczególnych złożach gazowych Niżu Polskiego (według danych z PGNiG SA Oddz. Zielona Góra)

\section{Analiza warunków geologicznych Niżu Polskiego i wybranych złóż oraz systemy energetyczne}

Na obszarze niecki zielonogórskiej mamy do czynienia z dwoma różnymi typami litologicznymi skał zbiornikowych: piaskowcami oraz skałami węglanowymi (wapienie i dolomity). W ogólnej liczbie odkrytych złóż w kilkunastu z nich skałami zbiornikowymi są piaskowce saksonu, w kilku - skały węglanowe wapienia podstawowego oraz w kilku - jedne i drugie. Skałami zbiornikowymi są piaskowce drobno- i średnioziarniste. W stropowych partiach serii złożowych piaskowce posiadają lepiszcze ilasto-węglanowe, i to w dość dużej ilości, co powoduje, że są zwięzłe. Rodzaj lepiszcza decyduje również o ich zabarwieniu. Są to piaskowce szare i jasnoszare. Poniżej występują piaskowce czerwonobrunatne, niekiedy różowe, drobno- i średnioziarniste. Zabarwienie to pochodzi od lepiszcza ilasto-żelazistego. Utwory wapienia podstawowego zalegają bezpośrednio nad utworami czerwonego spągowca. Charakteryzują się one wykształceniem węgla- nowym w postaci wapieni i dolomitów. Duże znaczenie jako kolektor gazowy odgrywa facja rafowa, występująca w południowobrzeżnej strefie basenu permskiego, oraz utwory węglanowe (wapienie masywowe), obecne w centralnej części basenu. Utwory czerwonego spągowca, występujące w niecce poznańskiej, reprezentowane są przez utwory autunu i saksonu. Utwory saksonu wykształcone są jako piaskowce oraz osady piaskowcowo-zlepieńcowate z podrzędnymi mułowcami i iłowcami. W strefach akumulacji gazu skałami zbiornikowymi są przeważnie piaskowce drobnoziarniste, średnioziarniste $\mathrm{z}$ domieszką materiału grubszego, przechodzące w piaskowce zlepieńcowate.

Ze względu na skład chemiczny gazu ziemnego złoża można podzielić na trzy typy:

- złoża wysokozaazotowane, o zawartości węglowodorów do $20 \%$ objętości, azotu ponad $70 \%$ oraz $\mathrm{H}_{2} \mathrm{~S}$, 
- złoża średniozaazotowane, zawierające gaz o zawartości do $60 \%$ objętości węglowodorów,

- złoża zawierające gaz o dużej zawartości węglowodorów, rzędu $60 \div 90 \%$ objętości.

System energetyczny złoża charakteryzują cechy, którymi z kolei są: procent końcowego sczerpania złoża, spadek ciśnienia złożowego oraz wydobycie płynów złożowych i zachowanie się odwiertów [20]. Płynami złożowymi są ropa naftowa, gaz ziemny i woda. Gdy płyny te wydobywają się same lub zostaną wydobyte przez przedsiębiorcę, ich miejsce musi zostać czymś wypełnione. Mogą to być rozszerzające się sub- stancje pozostałe w złożu (w tym również skała) lub substancje dopływające do złoża z zewnętrznych obszarów. Podstawowy system energetyczny każdego złoża określany jest przez charakter tych dopływających substancji.

Złoża gazu ziemnego na Niżu Polskim posiadają wolumetryczne, sprężysto-naporowe i sprężysto-ekspansyjno-wodnonaporowe warunki energetyczne. Zasoby są sczerpane w ponad $60 \%$ i dają perspektywę na dalsze lata.

Do analizy wybrano złoża Paproć i Wilków, ze względu na wielkości zasobów, jak również położenie: złoże Paproć - niecka poznańska, złoże Wilków - niecka zielonogórska.

\section{Złoże gazu ziemnego Paproć}

Złoże gazu ziemnego Paproć znajduje się w północnej części obszaru przedsudeckiego, na N skłonie wału wolsztyńskiego. W budowie geologicznej rejonu złoża biorą udział cztery kompleksy strukturalne: kaledoński, waryscyjski, permsko-mezozoiczny i kenozoiczny. Złoże zakumulowane w utworach czerwonego spągowca jest złożem wielowarstwowym. Strefę gazonośną stanowi wyklinowujący się kompleks piaszczysto-zlepieńcowaty saksonu oraz stropowa część autunu. Złoże Paproć zawarte w utworach czerwonego spągowca jest złożem wielowarstwowym, a pułapka ma charakter stratygraficzno-litologiczny. Gaz znajduje się w przekładkach piaszczystych występujących w piaszczysto-zlepieńcowatej serii gazonośnej czerwonego spągowca. Za serię gazonośną w kolejnych otworach uważa się utwory piaszczysto-zlepieńcowate zawarte pomię-

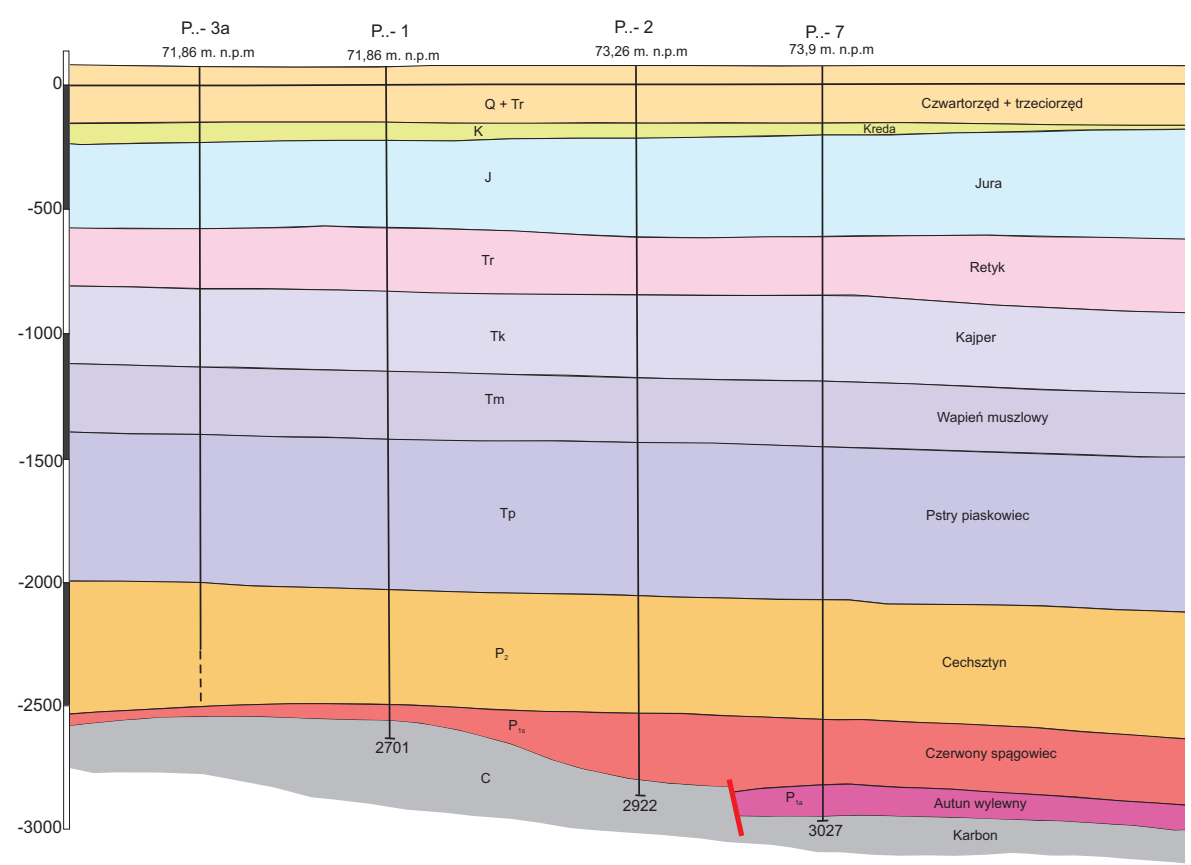

Rys. 7. Złoże gazu ziemnego Paproć; przekrój geologiczny poprzeczny 1:10 000 (opracowanie: W. Sumiak, W. Piesik-Buś według danych z PGNiG SA Oddz. Zielona Góra) dzy wapieniem podstawowym cechsztynu a najniższą przekładką piaszczystą, dającą przemysłową produkcję gazu [10-12, 14].

Po przeanalizowaniu dostępnych danych zasobowych, bilansów zasobowych i po przeprowadzeniu szczegółowej analizy zasobowo-geologiczno-ekonomicznej stwierdzono, że: zasoby geologiczne pierwotne złoża Paproć N wynosiły $6500 \mathrm{mln} \mathrm{m}^{3}$ gazu, wydobywalne - $4450 \mathrm{mln} \mathrm{m}^{3}$, przemysłowe $-4440,46 \mathrm{mln} \mathrm{m}^{3}$. W 2015 roku zasoby wydobywalne wynosiły $3438,8 \mathrm{mln} \mathrm{m}^{3}$, a przemysłowe 3228,63 $\mathrm{mln} \mathrm{m}^{3}$. Do 2015 roku wydobyto ze złoża $1211,8 \mathrm{mln} \mathrm{m}^{3}$ gazu, zaś w samym 2015 roku wydobycie wynosiło $182,45 \mathrm{mln} \mathrm{m}^{3}$. Orientacyjny czas eksploatacji, jaki pozostał na złożu, szacuje się mniej więcej na 17 lat. W omawianych w bilansie latach 2007-2015 wydobyto ze złoża 1208,7 $\mathrm{mln} \mathrm{m}^{3}$ gazu (rysunki 7 i 8).

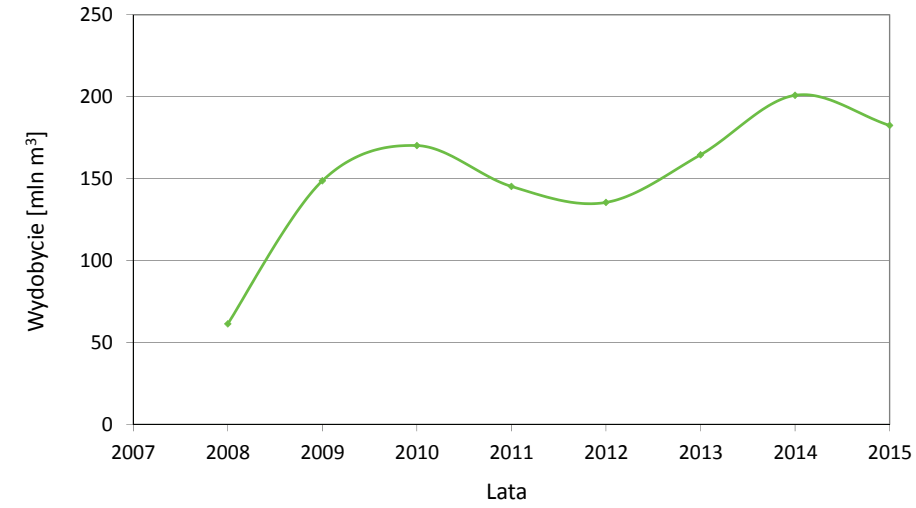

Rys. 8. Złoże gazu ziemnego Paproć. Wykres wielkości wydobycia gazu ziemnego w latach 2007-2015 (według bilansów zasobów PIG - PIB [1-9]) 


\section{Złoże gazu ziemnego Wilków}

Złoże gazu ziemnego Wilków jest złożem masywowym związanym z przystropową partią piaszczystych utworów czerwonego spągowca. Złoże posiada kształt wydłużonej brachyantykliny i od dołu na całej powierzchni ograniczone jest wodą podścielającą, której poziom zalegania ustalono na głębokości 1511 m p.p.m. Górną granicę złoża stanowi wapień podstawowy wraz z poziomem łupków miedzionośnych oraz utwory anhydrytowo-solne cyklotemu Werra. Wapień podstawowy w rejonie Wilkowa posiada niewielką miąższość i charakteryzuje się słabymi własnościami kolektorskimi. Gaz ziemny złoża Wilków zakumulowany jest $\mathrm{w}$ przystropowej partii piaszczystych utworów saksonu. Maksymalna miąższość serii gazonośnej wynosi $63,7 \mathrm{~m}$. Seria złożowa zbudowana jest z różnoziarnistych piaskowców kwarcowych, w partiach przystropowych barwy szarej, przechodzących w piaskowce o zabarwieniu czerwonym i brunatnoczerwonym. Występujące w stropie piaskowce szare są słabo zwięzłe, kruche i rozsypliwe. Są to piaskowce drobnoziarniste i na ogól słabo wysortowane. Występujące poniżej piaskowce czerwone charakteryzują się warstwowaniem równoległym lub skośnym, partiami frakcjonalnym. Złoże odkryto w 1979 roku odwiertem Wilków-1. Eksploatację złoża Wilków rozpoczęto w grudniu 1988 roku. Dominującymi warunkami energetycznymi złoża są warunki ekspansyjne. Po przeanalizowaniu dostępnych danych zasobowych, bilansów zasobowych i po przeprowadzeniu szczegółowej analizy zasobowo-geologiczno-ekonomicznej stwierdzono, że: zasoby geologiczne pierwotne złoża Wilków wynosiły $5700 \mathrm{mln} \mathrm{m}^{3}$ gazu, wydobywalne $-4400 \mathrm{mln} \mathrm{m}^{3}$, a przemysłowe $-4288,87 \mathrm{mln} \mathrm{m}^{3}$.
W 2015 roku zasoby wydobywalne wynosiły $806,24 \mathrm{mln} \mathrm{m}^{3}$, a przemysłowe $696,51 \mathrm{mln}^{3}$. Do 2015 roku wydobyto ze złoża $3592 \mathrm{mln} \mathrm{m}^{3}$ gazu, zaś w samym 2015 roku wydobycie wynosiło $90,78 \mathrm{mln}^{3}$. Orientacyjny czas eksploatacji, jaki pozostał na złożu, szacuje się mniej więcej na 7 lat. W omawianych w bilansie latach 2007-2015 wydobyto ze złoża 932,96 mln $\mathrm{m}^{3}$ gazu (rysunki 9 i 10).

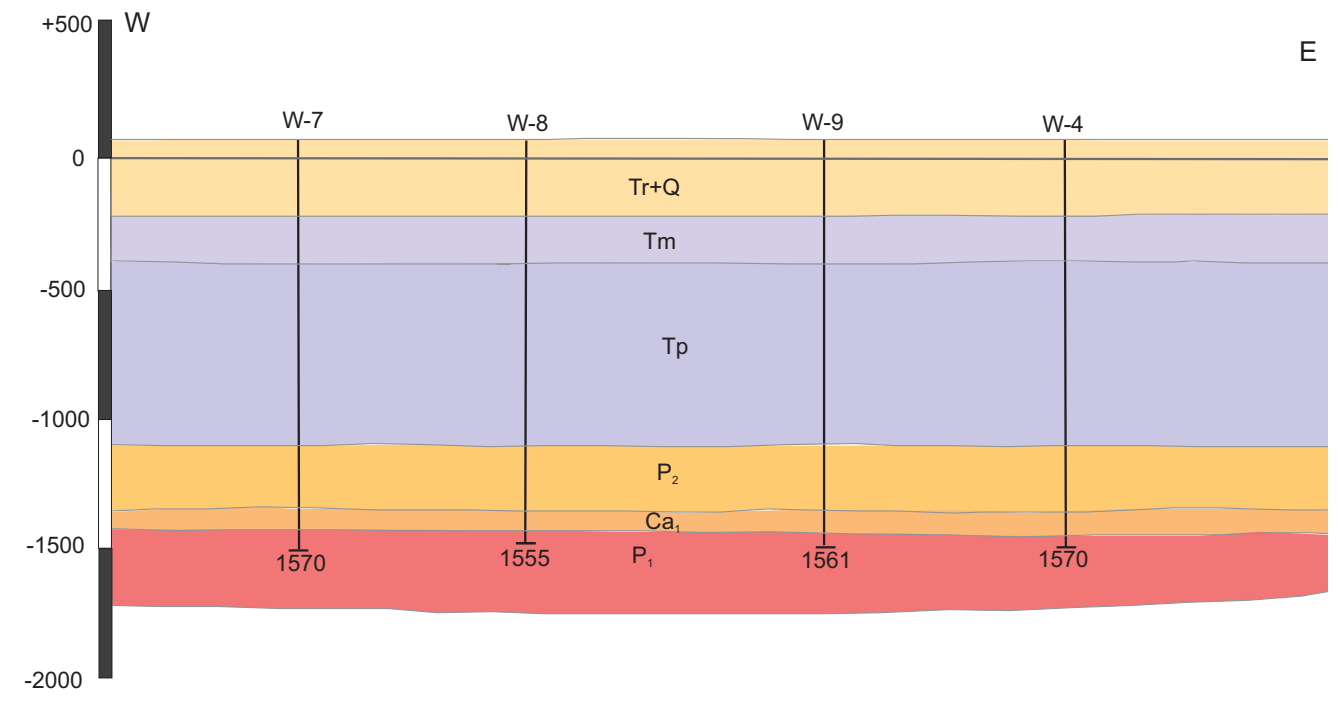

Rys. 9. Złoże gazu ziemnego Wilków; przekrój geologiczny poprzeczny $1: 25000$ (oprac. W. Piesik-Buś według danych z PGNiG SA Oddz. Zielona Góra)

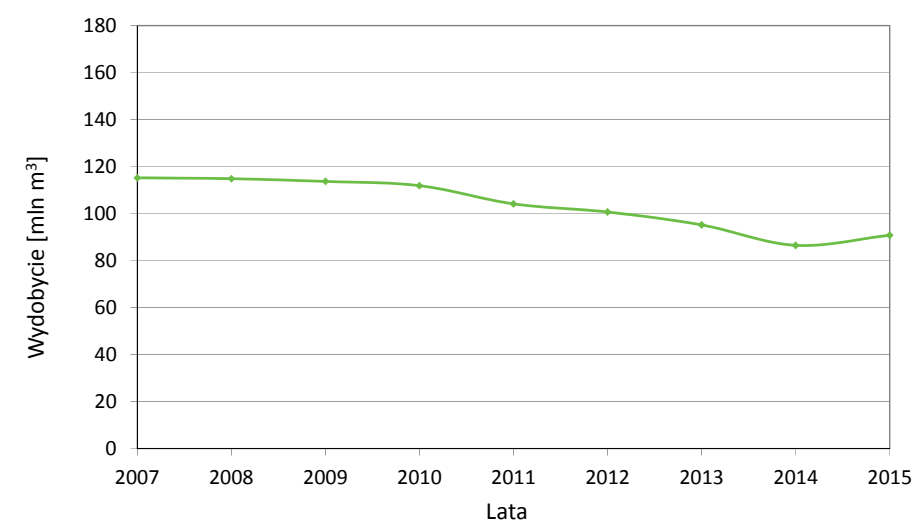

Rys. 10. Złoże gazu ziemnego Wilków; wykres wielkości wydobycia gazu ziemnego w latach 2007-2015 (według bilansów zasobów PIG - PIB [1-9])

\section{Stan zasobów w wybranych złożach gazowych Niżu Polskiego w latach 2007-2015}

Wielkości zasobów geologicznych wydobywalnych na wybranych złożach Niżu Polskiego na przestrzeni lat 2007-2015 przedstawia tablica 1 oraz rysunki 11 i 12 . Omawiane złoża pracują w wolumetrycznych, sprężysto-naporowych i sprężysto-ekspansyjno-wodnonaporowych warunkach energetycznych. 
Tablica 1. Zestawienie zasobów, wydobycia i czasu eksploatacji na wybranych złożach Niżu Polskiego (według danych z PGNiG SA Oddz. Zielona Góra, Bilans zasobów PIG - PIB)

\begin{tabular}{|c|c|c|c|c|c|c|}
\hline \multirow[t]{2}{*}{ Złoże } & $\begin{array}{l}\text { Zasoby } \\
\text { geologiczne }\end{array}$ & $\begin{array}{c}\text { Zasoby } \\
\text { wydobywalne }\end{array}$ & $\begin{array}{c}\text { Zasoby } \\
\text { wydobywalne } \\
\text { w } 2015 \text { r. }\end{array}$ & $\begin{array}{l}\text { Wydobycie } \\
\text { do } 2015 \text { r. }\end{array}$ & $\begin{array}{l}\text { Wydobycie } \\
\text { w } 2015 \text { r. }\end{array}$ & \multirow{2}{*}{$\begin{array}{l}\text { Czas dalszej } \\
\text { eksploatacji } \\
\text { [lata] }\end{array}$} \\
\hline & \multicolumn{5}{|c|}{$\left[\mathrm{mln} \mathrm{m}^{3}\right]$} & \\
\hline Bogdaj-Uciechów & 17784,38 & 15800,00 & 3531,14 & 12256,62 & 86,77 & 40,70 \\
\hline Brońsko & 28000,00 & 23800,00 & 15797,79 & 9400,00 & 781,00 & 19,19 \\
\hline Czeszów & 1933,00 & 1740,00 & 408,88 & 1330,00 & 4,83 & 77,78 \\
\hline Daszewo N & 1790,00 & 1415,00 & 999,47 & 415,53 & 25,25 & 36,90 \\
\hline Grochowice & 4000,00 & 2400,00 & 1147,58 & 1117,60 & 49,41 & 22,04 \\
\hline Kościan S & 12960,00 & 10360,00 & 3781,94 & 6578,00 & 370,87 & 10,20 \\
\hline Paproć-cz. spąg. & 6500,00 & 4450,00 & 3438,80 & 1211,80 & 182,45 & 17,20 \\
\hline Radlin & 14300,00 & 11070,00 & 3226,45 & 7843,50 & 178,94 & 18,03 \\
\hline Tarchały $\mathrm{Ca} 1+\mathrm{P} 1$ & 2722,00 & 2450,00 & 1537,75 & 912,25 & 17,18 & 89,51 \\
\hline Wierzowice & 1060,00 & 470,00 & 396,29 & 73,71 & 2,85 & 122,45 \\
\hline Wilków & 5700,00 & 4400,00 & 806,24 & 3592,00 & 90,78 & 7,60 \\
\hline Żuchlów & 25200,00 & 22000,00 & 1105,41 & 21000,00 & 228,98 & 4,17 \\
\hline
\end{tabular}
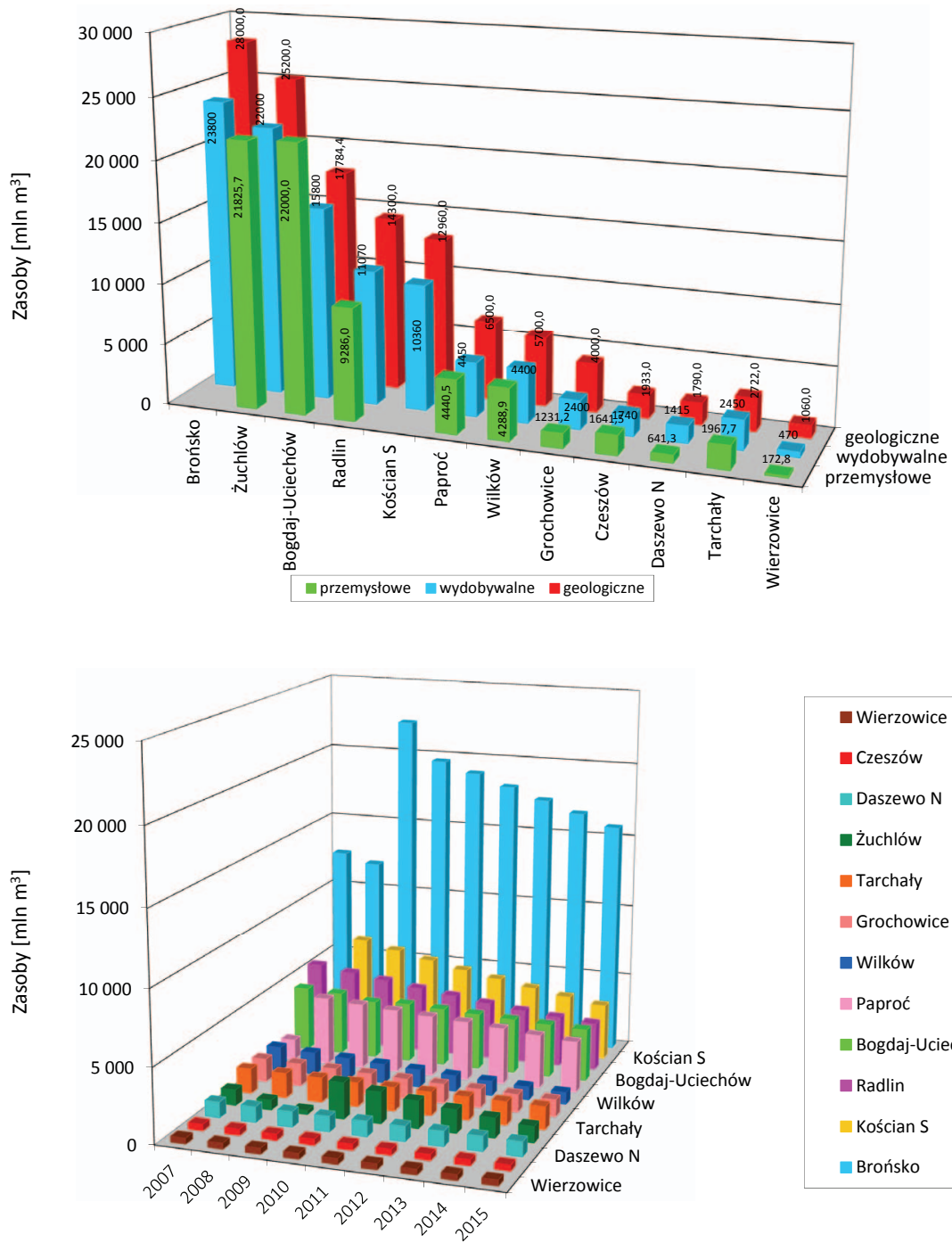

Rys. 11. Zestawienie wielkości zasobów pierwotnych gazu ziemnego w wybranych złożach Niżu Polskiego (według danych z PGNiG SA Oddz. Zielona Góra)
Rys. 12. Wykres wielkości zasobów wydobywalnych gazu ziemnego w wybranych złożach Niżu Polskiego na przestrzeni lat 2007-2015 (według bilansów zasobów PIG - PIB [1-9]) 


\section{Podsumowanie}

Zasoby gazu ziemnego na Niżu Polskim znajdują się, według bilansów zasobów PIG - PIB, w około 150 złożach. Do analizy zasobów zostało przeznaczonych 69 złóż (z zestawień otrzymanych z PGNiG SA Oddział Zielona Góra). Zasoby gazu tych złóż podzielono na zasoby początkowe geologiczne, początkowe wydobywalne i początkowe przemysłowe. Początkowe zasoby geologiczne z tych złóż wynosiły $169452,41 \mathrm{mln} \mathrm{m}^{3}$ gazu, początkowe zasoby wydobywalne - $146086 \mathrm{mln} \mathrm{m}^{3}$ gazu, a początkowe zasoby przemysłowe $95772,82 \mathrm{mln} \mathrm{m}^{3}$ gazu. Według bilansu PIG - PIB z 2015 roku zasoby wydobywalne z tych złóż wynosiły $62314,23 \mathrm{mln} \mathrm{m}^{3}$, zasoby przemysłowe $-41005,92 \mathrm{mln} \mathrm{m}^{3}$, zaś wydobycie w $2015 \mathrm{roku}-3640,75 \mathrm{mln} \mathrm{m}$.

Na podstawie bilansu zasobów gazu z 2015 roku rozdzielono zasoby na wydobywalne bilansowe i przemysłowe. Następnie, po przeglądzie zasobów, wydzielono złoża o zasobach wydobywalnych bilansowych do $100 \mathrm{mln} \mathrm{m}^{3}$ gazu, do $500 \mathrm{mln} \mathrm{m}^{3}$, powyżej $500 \mathrm{mln} \mathrm{m}^{3}$ i powyżej $1 \mathrm{mld} \mathrm{m}^{3}$. Okazało się, że 21 złóż z Niżu posiada zasoby wydobywalne bilansowe do $100 \mathrm{mln} \mathrm{m}^{3}$, 28 złóż zasoby do $500 \mathrm{mln} \mathrm{m}^{3}$, 7 złóż zasoby powyżej $500 \mathrm{mln} \mathrm{m}^{3}$ i 13 złóż zasoby powyżej $1 \mathrm{mld} \mathrm{m}^{3}$. Jeśli chodzi o zasoby przemysłowe w 2015 roku, również zostały one podzielone w ten sam sposób co zasoby wydobywalne. 31 złóż z Niżu posiada zasoby przemysłowe do $100 \mathrm{mln} \mathrm{m}^{3}$ gazu, 21 złóż do $500 \mathrm{mln} \mathrm{m}^{3}, 6$ złóż powyżej $500 \mathrm{mln} \mathrm{m}^{3}$ i 8 złóż powyżej 1 mld m³ . Łącznie ze złóż Niżu Polskiego w 2015 roku wydobyto $3640,75 \mathrm{mln} \mathrm{m}^{3}$ gazu.

Do szczegółowej analizy zasobowej wybrano 12 złóż Niżu Polskiego: Bogdaj-Uciechów, Brońsko, Czeszów, Daszewo N, Grochowice, Kościan S, Paproć, Radlin, Tachały, Wierzowice, Wilków i Żuchlów. Gaz skumulowany w tych złożach zalega w czerwonym spągowcu, wapieniu podstawowym, dolomicie głównym i karbonie [16-20].

Zasoby pierwotne geologiczne z tych złóż wynosiły $117294,38 \mathrm{mln} \mathrm{m}^{3}$ gazu, zasoby pierwotne wydobywalne - $100355,00 \mathrm{mln} \mathrm{m}^{3}$ gazu, a zasoby pierwotne przemysłowe $-60058,32 \mathrm{mln} \mathrm{m}^{3}$ gazu. W 2015 roku zasoby wydoby-

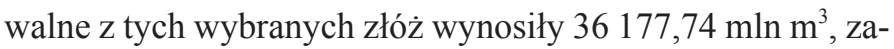
soby przemysłowe $-26037,6 \mathrm{~m}^{3}$, a wydobycie gazu w 2015 roku - 2019,31 mln $\mathrm{m}^{3}$. Wydobycie gazu z omawianych złóż na przestrzeni lat 2007-2015 wynosiło $19350,77 \mathrm{mln} \mathrm{\textrm {m } ^ { 3 }}$.

Tablica 2. Zestawienie własności eksploatacyjnych dodatkowo wybranych złóż (według bilansu zasobów PIG - PIB zestawiła W. Piesik-Buś)

\begin{tabular}{|c|c|c|c|c|c|c|}
\hline \multirow[t]{2}{*}{ Złoże } & $\begin{array}{c}\text { Zasoby } \\
\text { wydobywalne } \\
\text { w } 2015 \text { r. }\end{array}$ & $\begin{array}{l}\text { Wydobycie } \\
\text { w } 2015 \text { r. }\end{array}$ & $\begin{array}{l}\text { Czas dalszej } \\
\text { eksploatacji }\end{array}$ & $\begin{array}{l}\text { Ciśnienie denne } \\
\text { statyczne (pds) } \\
\text { aktualne }\end{array}$ & $\begin{array}{c}\text { Liczba } \\
\text { odwiertów }\end{array}$ & \multirow[t]{2}{*}{ System energetyczny złoża } \\
\hline & {$\left[\mathrm{mln} \mathrm{m}^{3}\right]$} & {$\left[\mathrm{mln} \mathrm{m}^{3}\right]$} & [lata] & {$[\mathrm{MPa}]$} & [szt.] & \\
\hline Daszewo N & 999,47 & 25,25 & 36,90 & 16,73 & 9 & ekspansyjno-naporowy \\
\hline Czeszów & 408,88 & 4,83 & 77,78 & 8,50 & 17 & ekspansyjno-naporowy \\
\hline Grochowice & 1147,58 & 49,41 & 22,04 & 11,50 & 10 & wolumetryczne \\
\hline Tarchały & 1537,75 & 17,18 & 89,51 & 12,50 & 33 & ekspansyjno-wodnonaporowy \\
\hline Wierzowice & 396,29 & 2,85 & 122,45 & 10,50 & 12 & ekspansyjno-wodnonaporowy \\
\hline
\end{tabular}

Tablica 3. Zestawienie parametrów wybranych złóż gazu ziemnego (obliczył B. Filar)

\begin{tabular}{|c|c|c|c|c|c|c|}
\hline \multirow[t]{2}{*}{ Złoże } & $\begin{array}{c}\text { Głębokość } \\
\text { konturu }\end{array}$ & $\begin{array}{l}\text { Wydobycie } \\
\text { w } 2015 \text { r. }\end{array}$ & $\begin{array}{c}\text { Liczba } \\
\text { odwiertów }\end{array}$ & $\begin{array}{l}\text { Wydobycie } \\
\text { na odwiert }\end{array}$ & Koszt odwiertu & $\begin{array}{c}\text { Czas zwrotu } \\
\text { kosztu odwiertu }\end{array}$ \\
\hline & [m p.p.m.] & {$\left[\mathrm{mln} \mathrm{m}^{3}\right]$} & [szt.] & {$\left[\mathrm{mln} \mathrm{m}^{3}\right]$} & {$[\mathrm{mln} \mathrm{z} / /]$} & [lata] \\
\hline Daszewo N & $-2900,0$ & 25,25 & 9 & 2,806 & 18,0 & 6,4 \\
\hline Czeszów & $-1370,0$ & 4,83 & 17 & 0,284 & 10,4 & 36,6 \\
\hline Grochowice & $-1596,0$ & 49,41 & 10 & 4,941 & 12,3 & 2,5 \\
\hline Tarchały & $-1620,0$ & 17,18 & 33 & 0,521 & 12,3 & 23,6 \\
\hline Wierzowice & $-1237,5$ & 2,85 & 12 & 0,238 & 9,8 & 41,2 \\
\hline
\end{tabular}




\section{Wnioski}

1. Złoża Niżu Polskiego posiadają wolumetryczne, sprężysto-naporowe i sprężysto-ekspansyjno-wodnonaporowe warunki energetyczne. Zasoby są sczerpane w ponad $60 \%$ i dają perspektywę na dalsze lata.

2. W związku z dużym szacowanym okresem eksploatacji złóż: Czeszów (77 lat), Daszewo N (36 lat), Grochowice (22 lata), Tarchały (89 lat), Wierzowice (122 lata) powinny zostać one poddane szczegółowej analizie geologiczno-eksploatacyjnej wykonanej pod kątem możli- wości zwiększenia tempa sczerpania ich zasobów (tablice 1-3).

3. Szacunkowo obliczono koszt odwiercenia nowego odwiertu przez głębokość zalegania konturu złoża oraz wydobycie na średni odwiert. Obliczono również czas zwrotu kosztu odwiercenia otworu w latach. Po przeanalizowaniu dochodzimy do wniosku, że najlepszymi złożami do inwestycji są złoża Daszewo N i Grochowice, gdyż mają krótki czas zwrotu inwestycji, tj. od 2,5 roku do 6,4 roku.

Prosimy cytować jako: Nafta-Gaz 2018, nr 5, s. 543-551, DOI: 10.18668/NG.2018.07.08

Artykuł nadesłano do Redakcji 14.11.2017 r. Zatwierdzono do druku 13.03.2018 r.

Artykuł powstał na podstawie pracy statutowej pt.: Analiza aktualnego stanu sczerpania zasobów gazu ziemnego w złożach zapadliska przedkarpackiego - praca INiG - PIB na zlecenie MNiSW; nr zlecenia: 215/0081/16/01, nr archiwalny KP-4100-81/2016.

\section{Literatura}

[1] Bilans zasobów kopalin i wód podziemnych w Polsce według stanu na 31 grudnia 2007. Państwowy Instytut Geologiczny Państwowy Instytut Badawczy.

[2] Bilans zasobów kopalin i wód podziemnych w Polsce według stanu na 31 grudnia 2008. Państwowy Instytut Geologiczny Państwowy Instytut Badawczy.

[3] Bilans zasobów kopalin i wód podziemnych w Polsce według stanu na 31 grudnia 2009. Państwowy Instytut Geologiczny Państwowy Instytut Badawczy.

[4] Bilans zasobów kopalin i wód podziemnych w Polsce według stanu na 31 grudnia 2010. Państwowy Instytut Geologiczny Państwowy Instytut Badawczy.

[5] Bilans zasobów kopalin i wód podziemnych w Polsce według stanu na 31 grudnia 2011. Państwowy Instytut Geologiczny Państwowy Instytut Badawczy.

[6] Bilans zasobów kopalin i wód podziemnych w Polsce według stanu na 31 grudnia 2012. Państwowy Instytut Geologiczny Państwowy Instytut Badawczy.

[7] Bilans zasobów kopalin i wód podziemnych w Polsce według stanu na 31 grudnia 2013. Państwowy Instytut Geologiczny Państwowy Instytut Badawczy.

[8] Bilans zasobów kopalin i wód podziemnych w Polsce według stanu na 31 grudnia 2014. Państwowy Instytut Geologiczny Państwowy Instytut Badawczy.

[9] Bilans zasobów kopalin i wód podziemnych w Polsce według stanu na 31 grudnia 2015. Państwowy Instytut Geologiczny Państwowy Instytut Badawczy.

[10] Buniak A., Kwolek K., Kiersnowski H., Kuberska M.: Perspektywy odkrycia złóż gazu ziemnego (typu tight gas) w piaskowcach eolicznych w basenie górnego czerwonego spagowca. Konferencja Naukowo-Techniczna Geopetrol 2008, Prace Instytutu Nafty i Gazu 2008, nr 150, Sekcja: geologia i geofizyka, s. 61-66.

[11] Burzewski W., Górecki W.: Zasoby prognostyczne - nieodkryty potencjat gazu ziemnego w polskim basenie czerwonego spagowca. Geologia 2009, t. 35, z. 2/1, s. 123-128.

[12] Kiersnowski H., Buniak A., Kuberska M., Srokowska-Okońska A.: Występowanie gazu ziemnego zamkniętego w piaskow- cach czerwonego spagowca Polski. Przegląd Geologiczny 2010, vol. 58, nr 4, s. 335-346.

[13] Kozak E.: Raport o stanie środowiska 2010.

[14] Mokrzycki E., Ney R., Siemek J.: Światowe zasoby surowców energetycznych - wnioski dla Polski. Rynek Energii 2008, nr 6, s. 3.

[15] Ocena zasobów wydobywalnych gazu ziemnego i ropy naftowej $w$ formacjach tupkowych dolnego paleozoiku w Polsce (basen battycko-podlasko-lubelski). Raport pierwszy. Państwowy Instytut Geologiczny - Państwowy Instytut Badawczy, Warszawa, marzec 2012.

[16] Piesik-Buś W.: Analiza produktywności czerwonego spagowca monokliny przedsudeckiej ze szczególnym uwzględnieniem niecki zielonogórskiej i poznańskiej. Wiadomości Naftowe i Gazownicze 2015, nr 4, s. 4-9.

[17] Piesik-Buś W.: Analiza przydatności wybranych złóż gazu ziemnego zapadliska przedkarpackiego do konwersji na PMG. Nafta-Gaz 2016, nr 2, s. 95-101, DOI: 10.18668/NG.2016.02.03.

[18] Piesik-Buś W.: Charakterystyka chemizmu wód wgtębnych basenu permskiego monokliny przedsudeckiej $w$ świetle interpretacji wskaźników hydrochemicznych. Wiadomości Naftowe i Gazownicze 2014, nr 7, s. 4-8.

[19] Piesik-Buś W., Miziołek M.: Bilans stanu zasobów gazu ziemnego na przykładzie złóż zapadliska przedkarpackiego. Nafta-Gaz 2016, nr 11, s. 48-54, DOI: 10.18668/NG.2016.11.08.

[20] Szejk 2009, nr 3; Szejk 2010, nr 1; Szejk 2011, nr 9; Szejk 2013, nr 1; Szejk 2013, nr 2; Szejk 2013, nr 3; Szejk 2013, nr 4; Szejk 2014, nr 1; Szejk 2014, nr 2. Artykuły z czasopisma PGNiG S.A. Oddział w Zielonej Górze.

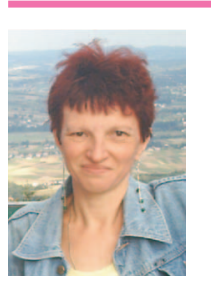

Mgr inż. Wacława PIESIK-BUŚ

Starszy specjalista badawczo-techniczny w Zakładzie Podziemnego Magazynowania Gazu. Instytut Nafty i Gazu - Państwowy Instytut Badawczy ul. Lubicz 25 A

31-503 Kraków

E-mail:piesik@inig.pl 